\title{
Integrative Approaches Utilizing Oxytocin to Enhance Prosocial Behavior: From Animal and Human Social Behavior to Autistic Social Dysfunction
}

\author{
Hidenori Yamasue, ${ }^{1,2}$ Jason R. Yee, ${ }^{3}$ René Hurlemann, ${ }^{4}$ James K. Rilling, ${ }^{5}$ Frances S. Chen, ${ }^{6}$ \\ Andreas Meyer-Lindenberg, ${ }^{7}$ and Heike Tost ${ }^{7}$ \\ ${ }^{1}$ Departments of Neuropsychiatry, Graduate School of Medicine, The University of Tokyo, Bunkyo-ku, Tokyo 113-8655, Japan, ${ }^{2}$ Japan Science and \\ Technology Agency, CREST, Chiyoda-ku, Tokyo 102-0075, Japan, ${ }^{3}$ Translational Research in Neural Medicine, Discovery and Analytical Science, RTI \\ International, Research Triangle Park, North Carolina 27709, ${ }^{4}$ Department of Psychiatry, University of Bonn, 53105 Bonn, Germany, ${ }^{5}$ Department of \\ Anthropology, Psychiatry and Behavioral Sciences, Emory University, Atlanta, Georgia 30322, ${ }^{\circ}$ Department of Psychology, University of Freiburg, D-79104 \\ Freiburg, Germany, and ${ }^{7}$ Department of Psychiatry and Psychotherapy, Central Institute of Mental Health, University of Heidelberg, Medical Faculty \\ Mannheim, 68159 Mannheim, Germany
}

The prevalence of autism spectrum disorder (ASD) is as high as 1 in 100 individuals and is a heavy burden to society. Thus, identifying causes and treatments is imperative. Here, we briefly review the topics covered in our 2012 Society for Neuroscience Mini-Symposium entitled "Integrative Approaches Using Oxytocin to Enhance Prosocial Behavior: From Animal and Human Social Behavior to ASD's Social Dysfunction.” This work is not meant to be a comprehensive review of oxytocin and prosocial behavior. Instead, we wish to share the newest findings on the effects of oxytocin on social behavior, the brain, and the social dysfunction of ASD at the molecular, genetic, systemic, and behavior levels, in varied subjects ranging from animal models to humans suffering from autism for the purpose of promoting further study for developing the clinical use of oxytocin in treating ASD.

\section{Introduction}

Recent worldwide epidemiological studies have shown that at least 1 in every 100 people has some form of autism spectrum disorder (ASD) (Brugha et al., 2011; Kim et al., 2011; Autism and Developmental Disabilities Monitoring Network Surveillance Year 2008 Principal Investigators and CDC, 2012). However, there is no established pharmacological treatment for social dysfunction, the core feature of ASD. Thus, identifying the cause and treatment is imperative. Although an intensive search for the biological markers of ASD has provided some major advances in the understanding of genetic, neurobiological, and developmental underpinnings, many aspects of the disease spectrum are still poorly understood.

In the past decade, research from various fields has revealed that oxytocin (OT) plays an important role in social interactions that goes far beyond the previously documented effects in female reproduction (Carter, 2007; Donaldson and Young, 2008). Humans exposed to OT make more eye contact, feel increased in-group trust, and are better able to infer emotions from other peoples' facial expressions (Bartz et al., 2011a; Meyer-Lindenberg et al., 2011; Striepens et al., 2011; Van Ijzendoorn and Bakermans-Kranenburg,

\footnotetext{
Received July 13, 2012; revised Aug. 29, 2012; accepted Aug. 31, 2012.

We acknowledge the kind permission to use the picture of prairie voles by Drs. Todd H. Ahern and Larry J. Young. The authors declare no competing financial interests.

Correspondence should be addressed to Hidenori Yamasue, Department of Neuropsychiatry, Graduate School of Medicine, The University of Tokyo 7-3-1 Hongo, Bunkyo-ku, Tokyo 113-8655, Japan. E-mail: yamasue-tky@ umin.ac.jp.

DOI:10.1523/JNEUROSCI.3327-12.2012

Copyright $\odot 2012$ the authors $\quad 0270-6474 / 12 / 3214109-09 \$ 15.00 / 0$
}

2012). The beneficial roles of OT on social functioning led us to wonder whether the substance is possibly useful for ASD therapy. Clinical application of OT in the treatment of this disorder can provide some recourse to afflicted individuals and their families. Although pioneering clinical studies support this notion (Hollander et al., 2007; Andari et al., 2010; Guastella et al., 2010), much remains to be learned about the mechanisms by which OT modulates social behavior before it is ready for clinical use. Specifically, little is known about the mechanistic effects of OT on social brain circuits, which are at the core of the observed behavioral changes.

To facilitate the use of OT treatment for the social deficits of ASD, findings on the mechanisms of OT therapy on social effects and its neural underpinnings should be integrated from diverse research fields from basic animal models to clinical studies. With this in mind, we will share the newest findings from various laboratories from around the world in our 2012 Society for Neuroscience MiniSymposium as well as in this review. Although we share an interest in OT's effect on social behavior, our research covers a wide spectrum of modalities, including molecular biology, genetics, functional and structural neuroimaging, behavioral research, and clinical research. The study subjects also range broadly from experimental animals to nonclinical and clinical human populations.

Animal models: oxytocin, functional neural connectivity, and the promotion of social cohesion during an environmental stressor

Although there is mounting evidence implicating OT in socioemotional disorders in humans (Jacob et al., 2007; Goldman et 
al., 2008, 2011; Rubin et al., 2011; Dai et al., 2012), research using animal models, including rats, sheep, and mice (Winslow et al., 2000; Choleris et al., 2007; Leng et al., 2008; Nowak et al., 2011; Gabor et al., 2012), has been a catalyst by identifying basic behavioral processes, such as social recognition, parental bonding, and social antagonism, mediated or modulated by OT that become dysregulated in human mental illness. Prairie voles, in particular, have been useful in revealing OT's role in human sociality largely because they share with humans the tendency toward forming selective preferences for familiar conspecifics (Williams et al., 1992). In the context of mating and reproduction, this tendency is expressed as a selective preference to spend time with a bonded mate over an unfamiliar conspecific (Williams et al., 1992; Carter and Keverne, 2002). Biological adaptations that facilitate selective social preference likely arise because they offer adaptive benefits, helping individuals efficiently overcome the many stressors and challenges associated with survival and reproduction throughout the lifespan (Carter, 1998; Porges, 2003a). Selective social preference is integral to the expression of specific social behaviors, functioning heuristically to facilitate or inhibit the motivation to approach, avoid, or remain behaviorally quiescent across a wide range of varying social contexts (Porges, 2003b; Carter et al., 2008; McCall and Singer, 2012). In the context of stress, activation of the OT system may promote approach toward, affiliation with, and maintenance of proximity between familiar individuals (Engelmann et al., 1996; Carter and Altemus, 1997; Young, 2002). Indeed, OT signaling in areas such as the paraventricular nucleus of the hypothalamus and central amygdala play a critical role in modulating responses to stressful, fearful, and anxietyprovoking stimuli (Neumann et al., 2000a,b, 2002; Huber et al., 2005; Viviani et al., 2011). Behaviors that increase proximity between familiar individuals would allow more coordinated responses to stressful stimuli, such as sharing vigilance during stressful events that impact a social group (Carter and Altemus, 1997; McCarthy and Altemus, 1997; Silk et al., 2003; Silk and House, 2011; Seyfarth and Cheney, 2012). OT function appears to be essential to group cohesion in prairie voles (Carter et al., 1992; Cho et al., 1999) and in a variety of other species. Cohesiveness of mother-litter aggregations in rats increased with OT pretreatment (Kojima and Alberts, 2011), and inhibition of the OT system by antagonist administration in marmosets (Smith et al., 2010) and rats (van Leengoed et al., 1987) or OT receptor knockout in mice (Pobbe et al., 2012) resulted in decreased huddling behavior. Recent research with prairie voles by one of the authors (J.Y.) and his coresearchers suggests that OT treatment in the context of stress may shift functional neural connectivity in a manner that promotes social cohesion when there is a natural impulse to disperse. Systemic pretreatment of OT before a brief flooded cage stressor (which may mimic the threat of a flooded burrow in nature) resulted in a greater amount of time spent in sedentary social contact after being returned to the home cage. Voles pretreated with OT displayed elevated concentrations of plasma OT 95 min following the original injection, suggesting positive feedback potentiation of OT release in the context of environmental stress similar to that seen in the context of parturition (Russell et al., 2003). OT pretreatment did not change overall neural activation as measured by Fos expression in the paraventricular nucleus of the hypothalamus (PVN), a brain region critically involved in coordinating neuroendocrine and autonomic responses to stress. However, voles pretreated with OT displayed functional coupling between the PVN and cardioregulatory areas in the brainstem; blocking OT activity with an antagonist resulted in decoupling of activity in the PVN and brainstem, as was seen in voles pretreated with saline. Interestingly, functional coupling with the PVN was seen in brainstem nuclei that exert both sympathetic (rostral ventrolateral medulla) and parasympathetic (dorsal vagal complex and nucleus ambiguous) influences on the heart. OT pretreatment unexpectedly resulted in a trend toward heightened glucocorticoid levels, but this may in fact be adaptive during an environmental threat that necessitates mobilization (J.R. Yee, S.W. Porges, and C.S. Carter, unpublished observations). In conclusion, this new research suggests that OT may function as an antistress hormone by changing physiology and neural connectivity in a manner that facilitates social cohesion in the face of environmental threats that may otherwise promote dispersal.

\section{Evidence for a neuromodulatory role of oxytocin in human social cognition and behavior}

Current perspectives on the neuromodulatory effects of OT in the domain of human social cognition and behavior emphasize its potency as a facilitator of sociality. The basis of this prevailing view has progressed from animal research documenting a pivotal role of OT in promoting social bonding and attachment (Insel, 1992; Young et al., 1998; Insel and Young, 2001; Kendrick, 2004; Neumann, 2009; Insel, 2010) and controlling fear and stress responses (Neumann, 2002; Huber et al., 2005; Lukas et al., 2011; Viviani et al., 2011; Knobloch et al., 2012) to pharmacological challenge studies in healthy humans, which demonstrated beneficial effects of intranasal single-dose (24-48 IU) administration of OT on behavioral responses in various social-economic and social-cognitive tasks. These tasks have addressed, for instance, interpersonal trust and cooperation (Kosfeld et al., 2005; De Dreu, 2011), generosity (Zak et al., 2007), social recognition memory (Guastella et al., 2008a; Savaskan et al., 2008; Rimmele et al., 2009), social reinforcement learning and emotional empathy (Hurlemann et al., 2010), assessments of facial attractiveness and trustworthiness (Theodoridou et al., 2009), and self-perception (Cardoso et al., 2012). However, recent studies contrast with the notion that OT exerts uniformly positive effects on human social cognition and behavior in showing that the peptide can also promote envy and gloating (schadenfreude) (Shamay-Tsoory et al., 2009), ethnocentrism (including prejudice, xenophobia, and racial bias) (De Dreu et al., 2011), and outgroup derogation (De Dreu et al., 2010). In addition, OT has been implicated in impeded trust and cooperation as well as in negatively biased recollections of maternal care and closeness in insecurely or anxiously attached individuals (Bartz et al., 2010, 2011b). In an attempt to reconcile these conflicting findings, it has been hypothesized that the effects of OT on human social cognition and behavior result from reduced anxiety and/or reflect increased perceptual salience of social cues (Bartz et al., 2011a). The anxiolytic action of the peptide has indeed been shown as decreased endocrine and subjective responses to social stress (Heinrichs et al., 2003) or as reduced negative cognitive self-appraisal in individuals scoring high in trait anxiety (Alvares et al., 2012), whereas the social salience hypothesis has gained considerable support from studies showing increased eye contact (Guastella et al., 2008b) and improved "mind reading" from facial gestures (Domes et al., 2007a) following administration of OT. Whether these mechanisms ultimately yield positive or negative social outcomes may vary as a function of context and/or person-specific features (Bartz et al., 2011a). An alternative concept argues that emotional valence may be the dominant factor guiding the effects of OT on human social cognition and behavior, with OT promoting social approach to positive cues and inhibiting social withdrawal from 
negative ones (Kemp and Guastella, 2011). However, the neuromodulatory role of OT is not only extensively studied in healthy humans with the purpose of unraveling the psychobiological substrates of its social effects- based on a rapidly growing number of baseline plasma-level studies and treatment trials in clinical populations - it is also beginning to emerge as a target for adjunctive therapy of social-behavioral dysfunction in several mental disorders (Striepens et al., 2011), including ASD (Hollander et al., 2003, 2007; Andari et al., 2010; Guastella et al., 2010), borderline personality disorder (Bartz et al., 2011b; Simeon et al., 2011), schizophrenia (Feifel et al., 2010; Goldman et al., 2011; Pedersen et al., 2011), and social phobia (Guastella et al., 2009; Labuschagne et al., 2011). This clinical translation, if proven to be feasible, would substantially extend and make innovations in current treatments of these disorders.

\section{The neural substrates for effects of oxytocin on human social cognition and behavior}

Pharmaco-functional-MRI (fMRI) studies involving intranasal OT administration are helping to elucidate the neural mechanisms of OT's effects on human social cognition. Initial studies focused on face processing. These studies showed that OT modulates amygdala activity when viewing human face stimuli in a sexually dimorphic manner, with OT generally decreasing amygdala activation to emotional faces in men (Kirsch et al., 2005; Domes et al., 2007b; Petrovic et al., 2008) but increasing it in women (Domes et al., 2010). OT also seems to increase amygdala activation to threatening scenes in women (Lischke et al., 2012). In men, but not women, these results are consistent with the known anxiolytic effects of OT (Heinrichs et al., 2009). $\mathrm{OT}$ also decreases functional connectivity between the amygdala and brainstem effector sites of the autonomic nervous system during emotional face viewing in men (Kirsch et al., 2005). On the other hand, OT increases amygdala functional connectivity with a key mentalizing region, the medial prefrontal cortex, at rest (Sripada et al., 2012). Higher-resolution imaging studies have now begun to elucidate the specific amygdala subregions responsible for these effects (Gamer et al., 2010). Intranasal OT has also been shown to normalize heightened amygdala and medial prefrontal cortex activity associated with social anxiety disorder (Labuschagne et al., 2010, 2011). Given OT's role in motivating maternal care, recent studies have investigated its ability to modulate the neural response of women to infant cries and laughter (Riem et al., 2011, 2012). Results were interpreted to suggest that OT suppresses the aversive response to infant crying, represented in the amygdala, while augmenting the empathic response, represented in the insula. Finally, OT's effect on brain activity has been studied during social interaction, where it has been shown to dampen men's amygdala response to the feedback that a social partner is not trustworthy (Baumgartner et al., 2008). In nonhuman experimental animals, OT interacts with DA in the ventral striatum to promote social bonding (Young et al., 2005; Skuse and Gallagher, 2009). However, evidence for similar mechanisms in humans is limited to correlations between ventral striatum activity and plasma OT levels (Strathearn et al., 2009; Atzil et al., 2011). A recent study from one of the authors' (J.R.) laboratory asked whether OT would augment the ventral striatum response to a cooperative exchange with a same-sex but unfamiliar person (Rilling et al., 2012). In a double-blind, placebocontrolled study, 91 men between the ages of 18 and 22 years (mean, 20.2 years) were randomized to receive intranasal OT $(n=27)$, intranasal vasopressin (AVP) $(n=27)$ or intranasal placebo $(n=36)$. Afterward, they were imaged with fMRI as they played four sessions of a 30-round, sequential-choice iterated prisoner's dilemma game with either computer or assumed human partners. Relative to both AVP and placebo, OT increased the caudate nucleus response to reciprocated cooperation, which may augment the reward of reciprocated cooperation and/or facilitate learning that another person can be trusted. Moreover, the caudate nucleus response to reciprocated cooperation was positively correlated with plasma OT levels. OT also enhanced left amygdala activation in response to reciprocated cooperation. Finally, OT was associated with decreased amygdala functional connectivity with the brainstem compared with placebo (as expected), and increased amygdala functional connectivity with both the ventral anterior insula and the inferior lateral temporal cortex. These latter results suggest that OT may enhance the amygdala's ability to elicit subjective feeling states and enhance attention to salient social stimuli.

\section{The role of the oxytocin receptor gene (OXTR) in human social stress and cognition}

Molecular genetics provides a means of studying how naturally occurring variation in the human OT system relates to brain function and behavior. The OT receptor gene (OXTR) is located on chromosome 3p25, spans $17 \mathrm{~kb}$ (Inoue et al., 1994), and encodes a 389 aa polypeptide with seven transmembrane domains belonging to the class I G-protein-coupled receptor family (Gimpl and Fahrenholz, 2001). Genetic variation influencing the number, organization, or functioning of OT receptors would be expected to influence the efficacy of the OT signal in the brain. Indeed, initial studies have linked variation in OXTR to susceptibility for mental disorders characterized by social deficits, such as ASD (Wu et al., 2005; Jacob et al., 2007; Lerer et al., 2008; Yrigollen et al., 2008; Gregory et al., 2009; Tansey et al., 2010; Wermter et al., 2010; Campbell et al., 2011), schizophrenia (Montag et al., 2012), and severe aggressive behaviors in childhood (Malik et al., 2012).

Two intronic single-nucleotide polymorphisms (SNPs), rs53576 and rs2254298, linked to susceptibility for ASD have in several subsequent studies also been associated with socioemotional functioning in healthy individuals. The A allele of rs53576 has been associated with a larger startle response and reduced emotion-reading abilities (Rodrigues et al., 2009), reduced maternal sensitivity (Bakermans-Kranenburg and van Ijzendoorn, 2008), fewer affiliative displays (Kogan et al., 2011), reduced trust (Krueger et al., 2012), increased hormonal and neurocardiac reactivity to social stress (Norman et al., 2012), and lower optimism, mastery, and self-esteem (Saphire-Bernstein et al., 2011). The AA genotype of rs53576 has been associated with reduced positive affect in men (Lucht et al., 2009) and a reduced tendency to seek social support during distress when such behavior is culturally normative (Kim et al., 2010). Furthermore, the AA genotype of rs53576 has been associated with reduced physiological and psychological responsiveness to social support from a close friend before acute stress (Chen et al., 2011b). Variation at rs2254298 has been associated with prosociality (Israel et al., 2009); trait empathy (Wu et al., 2012); attachment anxiety in females and autism-spectrum quotient in males (Chen, 2012); infant-caregiver attachment security in non-Caucasians (Chen et al., 2011a); and parental touch during interactions with infants (Feldman et al., 2012).

Less scientific attention has been directed so far to the examination of other common genetic variants in OXTR, although a clear increase in interest is evident in the recent literature. A particularly interesting example is rs2268498 (T/C), a functional 
polymorphism in the promoter region of the gene that contributes to moral judgments (Walter et al., 2012) and negative emotionality (Montag et al., 2011), as well as the intronic variant rs7632287 (G/A) that has been associated with childhood social behavior and adult pair-bonding (Walum et al., 2012) as well as susceptibility to ASD (Campbell et al., 2011). In addition, rs 1042778 has also been associated with prosocial decision making (Israel et al., 2009) and parental touch (Feldman et al., 2012). However, a few null or contrasting effects have also been reported in studies examining these and other SNPs (Gillath et al., 2008; Apicella et al., 2010; Tansey et al., 2010).

Clearly, open questions remain regarding the patterns of associations obtained using the molecular genetic approach. Some of these questions may be resolved through replication studies, testing of larger sample sizes, and more comprehensive haplotype-based analyses. In addition, more studies examining functional interaction of OXTR genetic variation with other candidate genes that modulate the secretion of OT such as CD38 (Feldman et al., 2012), and other neurotransmitter cascades in brain such as the dopaminergic and serotonergic system (Luijk et al., 2011) (Montag et al., 2011) are needed. A pharmacogenetic approach, associating genetic variability with individual differences in response to intranasal OT (Marsh et al., 2012), may also help to clarify a mechanism through which intronic genotypic variability could have functional consequences.

The molecular genetic approach has made several contributions to OT research. First, it demonstrates that the effects of intranasally administered OT have parallels in naturally occurring individual differences. Second, it provides a means of studying OT system function in individuals (e.g., in infants and children, pregnant women, or lactating mothers) for whom OT administration could be problematic. In addition, this approach may also help to explain some of the individual response variability to OT administration that has been observed in prior studies. In combination with other fruitful methodologies, this approach promises to provide future insights regarding the human OT system.

\section{Neurogenetic effects of social risk variants in OXTR on limbic structure and function}

At the neural systems level, both human social behavior and social stress processing are shaped by a key regulatory circuitry including the amygdala, anterior cingulate cortex (ACC) and hypothalamus (Lederbogen et al., 2011; Meyer-Lindenberg et al., 2011). The structural and functional anatomy of these networks is highly heritable (Peper et al., 2007) and shaped by a multitude of genetic variants, some of them conferring risk for mental disorders (Pezawas et al., 2005; Meyer-Lindenberg et al., 2009). Thus, not surprisingly, the search for the limbic neural correlates of risk variants in OXTR has gained increasing popularity in the recent neuroscience literature. A particularly fruitful approach has been imaging genetics, a research strategy that combines neuroimaging and genetic mapping techniques to identify the intermediate neural mechanisms that translate genetic variation into complex behavioral phenotypes (Meyer-Lindenberg and Weinberger, 2006).

Specifically, two of the SNPs, rs53576 and rs2254298, which were introduced above, in the third intron of OXTR have been in the focus of prior imaging genetics work. The first study on allelic variation in rs53576 (Tost et al., 2010) was conducted in a large sample of healthy Caucasian adults and demonstrated an association between OXTR genotype and morphometric alterations of the hypothalamus and amygdala. Specifically, consistent with a prior report in ASD (Kurth et al., 2011), an allele-load-dependent decrease in hypothalamus gray matter volume was observed in rs53576 A allele carriers that predicted lower prosocial temperament specifically in males. Other allelic effects mapped to limbic areas interconnected to the hypothalamus, as revealed by reduced amygdala reactivity during emotional processing and increased structural connectivity of hypothalamus and dorsal ACC.

In addition, several studies have examined limbic brain structure in the context of rs2254298, a genetic polymorphism that has been repeatedly linked to ASD, although there has been heterogeneity regarding the risk-associated allele in populations of different ethnicity (Wu et al., 2005; Jacob et al., 2007; Liu et al., 2010). The first imaging genetics study in a large sample of healthy Japanese adults (Inoue et al., 2010) used manual tracing methods to derive amygdala volumes, and examined the relationship of these measures to seven SNPs and one haplotype block in OXTR linked to ASD. Consistent with a second smaller study in adolescents of mixed ethnicity (Furman et al., 2011), the authors detected an association of the rs2254298 A allele and larger amygdala volumes. These findings were not replicated in a subsequent large study in healthy Caucasians using voxel-based morphometry and automated amygdala segmentation methods (Tost et al., 2011). Instead, a significant decrease in hypothalamus volume and altered function of dorsal anterior cingulate gyrus during emotion processing was observed, a discrepancy in findings that may relate to differences in imaging methods and/or population stratification effects.

Other functional imaging genetics work in the field ( $\mathrm{O}^{\prime}$ Connell et al.2012) examined the effects of OXTR rs2268498 (T/C), a functional variant in the promoter region associated with negative emotionality (Montag et al., 2011), on the neural processing of emotional stimuli. Here (O'Connell et al., 2012), homozygotes of the $\mathrm{C}$ allele demonstrated a decreased response in the inferior occipital gyrus during the recognition of fearful facial expressions, an area crucial for the processing of visual emotional stimuli that has been shown to be directly modulated by OT in a previous pharmacological challenge study (Domes et al., 2010). In addition, a recent pharmaco-imaging genetics study (Sauer et al., 2012) demonstrated effects of a common variant in CD38 (rs3796863) that has been linked to lower plasma OT levels (Feldman et al., 2012) and risk for autism (Higashida et al., 2012) on neural response of the fusiform gyrus during visual processing of social stimuli. Here, a significant increase in brain activation was observed in risk allele carriers that was further enhanced through the intranasal application of OT.

Together, while some of the observed heterogeneities calls for further empirical clarification, these imaging genetics findings underscore that risk variants in OXTR and CD38 alter the structural and functional properties of neural regions of the extended limbic regulatory network, particularly in hypothalamus, amygdala, higher-order regulatory areas of the anterior cingulate gyrus, and relevant input areas of the circuitry involved in the visual processing of social stimuli such as the fusiform gyrus. Further research is needed to clarify existing conflicting associations at the neural systems level, and how exactly these neural alterations translate into behavior and predispose individuals to deficits in emotional reactivity and social behavior.

\section{Oxytocin and autistic social dysfunction}

As overviewed above, considering together the sexually dimorphic feature and prosocial effects of this neuropeptide, it was suggested that OT can contribute to the pathophysiology of ASD, a sexually dimorphic neurodevelopmental disorder with social deficits as a core feature, and that it could be a candidate thera- 


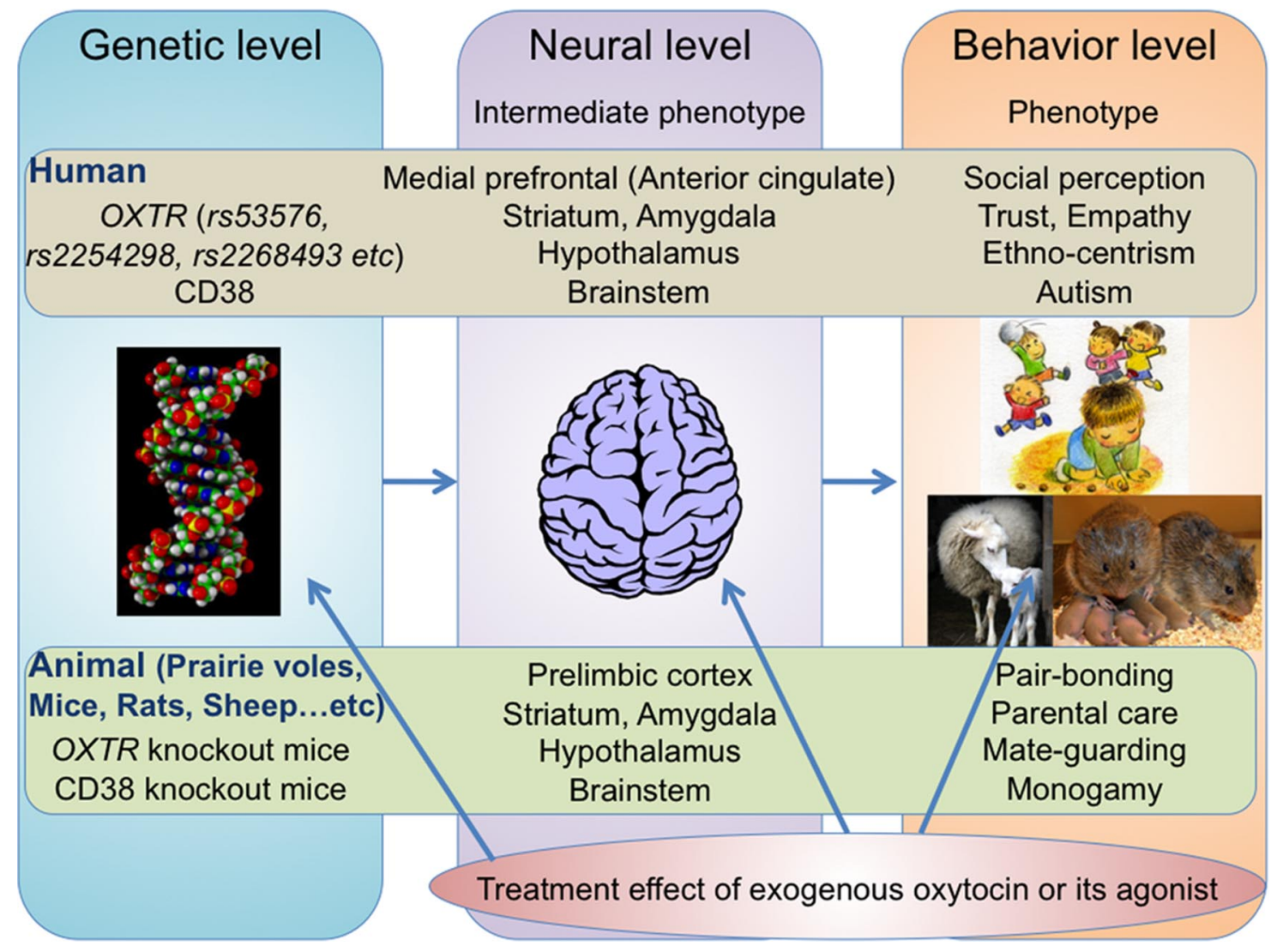

Figure 1. An integrative and translational model using oxytocin to enhance prosocial behavior: from animal and human social behavior to ASD's social dysfunction. Individual differences in genetically determined factors related to oxytocin such as SNPs in oxytocin receptor genes (OXTR) and CD38 in humans and OXTR/CD38 knock-0ut mice (Takayanagi et al., 2005; Jin et al., 2007) shape individual differences at the neural level such as function and structure in the limbic and paralimbic brain regions. Individual differences in these brain functions and structures should generate behavioral characteristics ranging from normal to extremes, including various social behaviors such as pair bonding, parental care, mate guarding, selective partner preference, monogamy, empathy, trust, ethnocentrism, social anxiety, social withdrawal, and ASD's social dysfunctions. Although human and animal studies are in different streams, genetic factors related to oxytocin and their neural and behavioral phenotypes are homologous at each level. It is expected that the therapeutic effects of exogenous oxytocin or its agonists can improve the behavioral and neural phenotypes associated with oxytocin-related genetic factors. Furthermore, early or long-term administration of oxytocin might even have an effect at the genetic (e.g., epigenetic, such as methylation of OXTR) level.

peutic agent for the symptoms of ASD (Yamasue et al., 2009). A lower-than-normal plasma OT level in ASD subjects (Modahl et al., 1998; Andari et al., 2010; Munesue et al., 2010) and an association of ASD with OXTR (Wu et al., 2005; Jacob et al., 2007; Lerer et al., 2008; Liu et al., 2010) further support a link between OT and ASD, although some inconsistency in association between ASD and OXTR was also recognized (Tansey et al., 2010; Campbell et al., 2011). Furthermore, several pioneering studies have suggested improvements in autistic behavioral and cognitive characteristics following administration of OT. Hollander et al. $(2003,2007)$ revealed the effects of intravenous injection of OT on autistic behavioral indices in their work. The authors examined 15 medication-free adults with ASD without intellectual disability who underwent two identical challenge days in which they received a continuous infusion of synthetic OT (pitocin) or placebo over $4 \mathrm{~h}$ in a randomized and double-blind design. The observed severity of repetitive behavior decreased gradually and significantly during OT infusion compared with that in individuals receiving placebo infusions. They further examined the effect of OT on affective speech comprehension using a similar study design (Hollander et al., 2007) to their previous study assessing repetitive behavior (Hollander et al., 2003). They observed that all participants, regardless of whether they received OT or placebo, showed improvements in affective speech comprehension from preinfusion to postinfusion. However, although those who received placebo first tended to revert to baseline after a 1 week infusion interval, those who received OT first retained the ability to accurately assign emotional significance to speech intonation in the speech comprehension task (Hollander et al., 2007). While their pioneering work using intravenous infusion of OT provides support for the use of OT in the treatment of ASD, more recent studies have used intranasal administration of OT in subjects with ASD (Andari et al., 2010; Guastella et al., 2010). Guastella et al. (2010) reported that male youths with ASD who received intranasal administration of OT showed significantly better performance on the "Reading the Mind in the Eyes" task, a widely used test of emotion recognition, compared with those receiving placebo. Another study examined the effect of intranasal OT on autistic deficits in social interactions (Andari et al., 2010). This study revealed that ASD individuals exhibited stronger interactions with the most socially cooperative partner and that they reported enhanced feelings of trust and preference with increased gazing time into the eyes after OT administration together with elevated plasma levels of OT. Although these findings, together with recent case reports showing improvements in autistic symptoms (Munesue et al., 2010; Kosaka et al., 2012), suggest the possibility that OT could be used to treat the currently untreatable autistic social dysfunction (Modi and Young, 2012), further large-scale studies or long-term trials are needed to assess the potential for further clinical application. In addition, the neural 
mechanisms by which OT improves autistic behavior are also unknown.

\section{Conclusion}

Our review covers the relationships of OT with animal/human social behavior as well as with psychopathological conditions such as autistic social dysfunction, and the neural underpinnings for these relationships, which are mainly distributed in limbic and paralimbic brain structures. The discussed neural systemslevel phenotypes not only link human genetic variation with behavior, but also human studies with animal studies, as the OT system is evolutionarily highly conserved in the mammalian brain and overlapping regions such as the amygdala, striatum, hypothalamus, and medial frontal cortex were indicated as shared neural effector sites in both humans and animals (Young et al., 2001; Hammock and Young, 2006; Inoue et al., 2010; Tost et al., 2010, 2011; Furman et al., 2011; Yamasue et al., 2011). As reviewed above, several different levels of evidence from animal models, genetic and human nonclinical and clinical studies support an association of OT with a wide range of social emotional behaviors from animal affiliation and bonding to human social perception, trust, and ethnocentrism. Accumulated evidence further supports the involvement of OT in the pathophysiology of disorders with pronounced social deficits including social anxiety disorder, borderline personality disorder, schizophrenia, and ASD. Clinical application of OT in the treatment of these disorders could provide a long-awaited and effective treatment option for afflicted individuals and their families. It is expected that OT treatment cannot only correct the behavioral phenotype but also the neural-level intermediate phenotype. Finally, it is even possible that OT may have favorable gene-level effects, such as epigenetic modulation of OXTR (Gregory et al., 2009) (Fig. 1). In the future, the cross-level integration of the steadily increasing body of evidence derived from basic OT research will be crucial to successfully translate these novel findings to clinical research and treatment development. In doing so, the existing evidence on OT's potential adverse effects will deserve particular attention. Specifically, it is imperative that future studies aim to unravel the potential social side effects and "contraindications" of OT as a treatment, as subject-specific biological and psychological characteristics as well as contextual factors may critically determine its efficiency.

\section{References}

Alvares GA, Chen NTM, Balleine BW, Hickie IB, Guastella AJ (2012) Oxytocin selectively moderates negative cognitive appraisals in high trait anxious males. Psychoneuroendocrinology. Advance online publication. Retrieved September 9, 2012. CrossRef Medline

Andari E, Duhamel JR, Zalla T, Herbrecht E, Leboyer M, Sirigu A (2010) Promoting social behavior with oxytocin in high-functioning autism spectrum disorders. Proc Natl Acad Sci U S A 107:4389-4394. CrossRef Medline

Apicella CL, Cesarini D, Johannesson M, Dawes CT, Lichtenstein P, Wallace B, Beauchamp J, Westberg L (2010) No association between oxytocin receptor (OXTR) gene polymorphisms and experimentally elicited social preferences. PLoS One 5:e11153. CrossRef Medline

Atzil S, Hendler T, Feldman R (2011) Specifying the neurobiological basis of human attachment: brain, hormones, and behavior in synchronous and intrusive mothers. Neuropsychopharmacology 36:2603-2615. CrossRef Medline

Bakermans-Kranenburg MJ, van Ijzendoorn MH (2008) Oxytocin receptor (OXTR) and serotonin transporter (5-HTT) genes associated with observed parenting. Soc Cogn Affect Neurosci 3:128-134. CrossRef Medline

Bartz JA, Zaki J, Ochsner KN, Bolger N, Kolevzon A, Ludwig N, Lydon JE (2010) Effects of oxytocin on recollections of maternal care and closeness. Proc Natl Acad Sci U S A 107:21371-21375. CrossRef Medline
Bartz JA, Zaki J, Bolger N, Ochsner KN (2011a) Social effects of oxytocin in humans: context and person matter. Trends Cogn Sci 15:301-309. CrossRef Medline

Bartz J, Simeon D, Hamilton H, Kim S, Crystal S, Braun A, Vicens V, Hollander E (2011b) Oxytocin can hinder trust and cooperation in borderline personality disorder. Soc Cogn Affect Neurosci 6:556-563. CrossRef Medline

Baumgartner T, Heinrichs M, Vonlanthen A, Fischbacher U, Fehr E (2008) Oxytocin shapes the neural circuitry of trust and trust adaptation in humans. Neuron 58:639-650. CrossRef Medline

Brugha TS, McManus S, Bankart J, Scott F, Purdon S, Smith J, Bebbington P, Jenkins R, Meltzer H (2011) Epidemiology of autism spectrum disorders in adults in the community in England. Arch Gen Psychiatry 68:459465. CrossRef Medline

Campbell DB, Datta D, Jones ST, Batey Lee E, Sutcliff JS, Hammock EA, Levitt P (2011) Association of oxytocin receptor (OXTR) gene variants with multiple phenotype domains of autism spectrum disorder. J Neurodev Disord 3:101-112. CrossRef Medline

Cardoso C, Ellenbogen MA, Linnen AM (2012) Acute intranasal oxytocin improves positive self-perceptions of personality. Psychopharmacology (Berl) 220:741-749. CrossRef Medline

Carter CS (1998) Neuroendocrine perspectives on social attachment and love. Psychoneuroendocrinology 23:779-818. CrossRef Medline

Carter CS (2007) Sex differences in oxytocin and vasopressin: implications for autism spectrum disorders? Behav Brain Res 176:170-186. CrossRef Medline

Carter CS, Altemus M (1997) Integrative functions of lactational hormones in social behavior and stress management. Ann N Y Acad Sci 807:164174. CrossRef Medline

Carter CS, Williams JR, Witt DM, Insel TR (1992) Oxytocin and social bonding. Ann N Y Acad Sci 652:204-211. CrossRef Medline

Carter CS, Grippo AJ, Pournajafi-Nazarloo H, Ruscio MG, Porges SW (2008) Oxytocin, vasopressin and sociality. Prog Brain Res 170:331-336. CrossRef Medline

Carter C, Keverne E, eds (2002) The neurobiology of social affiliation and pair-bonding. San Diego: Academic.

Chen F (2012) An oxytocin receptor gene variant predicts attachment anxiety in females and autism-spectrum traits in males. Soc Psychol Personal Sci 3:93-99. CrossRef

Chen FS, Barth ME, Johnson SL, Gotlib IH, Johnson SC (2011a) Oxytocin receptor (OXTR) polymorphisms and attachment in human infants. Front Psychol 2:200. CrossRef Medline

Chen FS, Kumsta R, von Dawans B, Monakhov M, Ebstein RP, Heinrichs M (2011b) Common oxytocin receptor gene (OXTR) polymorphism and social support interact to reduce stress in humans. Proc Natl Acad Sci U S A 108:19937-19942. CrossRef Medline

Cho MM, DeVries AC, Williams JR, Carter CS (1999) The effects of oxytocin and vasopressin on partner preferences in male and female prairie voles (Microtus ochrogaster). Behav Neurosci 113:1071-1079. CrossRef Medline

Choleris E, Little SR, Mong JA, Puram SV, Langer R, Pfaff DW (2007) Microparticle-based delivery of oxytocin receptor antisense DNA in the medial amygdala blocks social recognition in female mice. Proc Natl Acad Sci U S A 104:4670-4675. CrossRef Medline

Dai L, Carter CS, Ying J, Bellugi U, Pournajafi-Nazarloo H, Korenberg JR (2012) Oxytocin and vasopressin are dysregulated in williams syndrome, a genetic disorder affecting social behavior. PLoS One 7:e38513. CrossRef Medline

De Dreu CK (2011) Oxytocin modulates the link between adult attachment and cooperation through reduced betrayal aversion. Psychoneuroendocrinology 37:871-880. CrossRef Medline

De Dreu CK, Greer LL, Handgraaf MJ, Shalvi S, Van Kleef GA, Baas M, Ten Velden FS, Van Dijk E, Feith SW (2010) The neuropeptide oxytocin regulates parochial altruism in intergroup conflict among humans. Science 328:1408-1411. CrossRef Medline

De Dreu CK, Greer LL, Van Kleef GA, Shalvi S, Handgraaf MJ (2011) Oxytocin promotes human ethnocentrism. Proc Natl Acad Sci U S A 108: 1262-1266. CrossRef Medline

Domes G, Heinrichs M, Michel A, Berger C, Herpertz SC (2007a) Oxytocin improves "mind-reading" in humans. Biol Psychiatry 61:731-733. CrossRef Medline

Domes G, Heinrichs M, Gläscher J, Büchel C, Braus DF, Herpertz SC 
(2007b) Oxytocin attenuates amygdala responses to emotional faces regardless of valence. Biol Psychiatry 62:1187-1190. CrossRef Medline

Domes G, Lischke A, Berger C, Grossmann A, Hauenstein K, Heinrichs M, Herpertz SC (2010) Effects of intranasal oxytocin on emotional face processing in women. Psychoneuroendocrinology 35:83-93. CrossRef Medline

Domes G, Schulze L, Böttger M, Grossmann A, Hauenstein K, Wirtz PH, Heinrichs M, Herpertz SC (2010) The neural correlates of sex differences in emotional reactivity and emotion regulation. Hum Brain Mapp 31:758-769. CrossRef Medline

Donaldson ZR, Young LJ (2008) Oxytocin, vasopressin, and the neurogenetics of sociality. Science 322:900-904. CrossRef Medline

Engelmann M, Wotjak CT, Neumann I, Ludwig M, Landgraf R (1996) Behavioral consequences of intracerebral vasopressin and oxytocin: focus on learning and memory. Neurosci Biobehav Rev 20:341-358. CrossRef Medline

Feifel D, Macdonald K, Nguyen A, Cobb P, Warlan H, Galangue B, Minassian A, Becker O, Cooper J, Perry W, Lefebvre M, Gonzales J, Hadley A (2010) Adjunctive intranasal oxytocin reduces symptoms in schizophrenia patients. Biol Psychiatry 68:678-680. CrossRef Medline

Feldman R, Zagoory-Sharon O, Weisman O, Schneiderman I, Gordon I, Maoz R, Shalev I, Ebstein RP (2012) Sensitive parenting is associated with plasma oxytocin and polymorphisms in the OXTR and CD38 genes. Biol Psychiatry 72:175-181. CrossRef Medline

Furman DJ, Chen MC, Gotlib IH (2011) Variant in oxytocin receptor gene is associated with amygdala volume. Psychoneuroendocrinology 36: 891-897. CrossRef Medline

Gabor CS, Phan A, Clipperton-Allen AE, Kavaliers M, Choleris E (2012) Interplay of oxytocin, vasopressin, and sex hormones in the regulation of social recognition. Behav Neurosci 126:97-109. CrossRef Medline

Gamer M, Zurowski B, Büchel C (2010) Different amygdala subregions mediate valence-related and attentional effects of oxytocin in humans. Proc Natl Acad Sci U S A 107:9400-9405. CrossRef Medline

Gillath O, Shaver PR, Baek JM, Chun DS (2008) Genetic correlates of adult attachment style. Pers Soc Psychol Bull 34:1396-1405. CrossRef Medline

Gimpl G, Fahrenholz F (2001) The oxytocin receptor system: structure, function, and regulation. Physiol Rev 81:629-683. Medline

Goldman MB, Gomes AM, Carter CS, Lee R (2011) Divergent effects of two different doses of intranasal oxytocin on facial affect discrimination in schizophrenic patients with and without polydipsia. Psychopharmacology (Berl) 216:101-110. CrossRef Medline

Goldman M, Marlow-O’Connor M, Torres I, Carter CS (2008) Diminished plasma oxytocin in schizophrenic patients with neuroendocrine dysfunction and emotional deficits. Schizophr Res 98:247-255. CrossRef Medline

Gregory SG, Connelly JJ, Towers AJ, Johnson J, Biscocho D, Markunas CA, Lintas C, Abramson RK, Wright HH, Ellis P, Langford CF, Worley G, Delong GR, Murphy SK, Cuccaro ML, Persico A, Pericak-Vance MA (2009) Genomic and epigenetic evidence for oxytocin receptor deficiency in autism. BMC Med 7:62. CrossRef Medline

Guastella AJ, Mitchell PB, Mathews F (2008a) Oxytocin enhances the encoding of positive social memories in humans. Biol Psychiatry 64:256258. CrossRef Medline

Guastella AJ, Mitchell PB, Dadds MR (2008b) Oxytocin increases gaze to the eye region of human faces. Biol Psychiatry 63:3-5. CrossRef Medline

Guastella AJ, Howard AL, Dadds MR, Mitchell P, Carson DS (2009) A randomized controlled trial of intranasal oxytocin as an adjunct to exposure therapy for social anxiety disorder. Psychoneuroendocrinology 34:917923. CrossRef Medline

Guastella AJ, Einfeld SL, Gray KM, Rinehart NJ, Tonge BJ, Lambert TJ, Hickie IB (2010) Intranasal oxytocin improves emotion recognition for youth with autism spectrum disorders. Biol Psychiatry 67:692-694. CrossRef Medline

Hammock EA, Young LJ (2006) Oxytocin, vasopressin and pair bonding: implications for autism. Philos Trans R Soc Lond, B, Biol Sci 361:21872198. CrossRef Medline

Heinrichs M, Baumgartner T, Kirschbaum C, Ehlert U (2003) Social support and oxytocin interact to suppress cortisol and subjective responses to psychosocial stress. Biol Psychiatry 54:1389-1398. CrossRef Medline

Heinrichs M, von Dawans B, Domes G (2009) Oxytocin, vasopressin, and human social behavior. Front Neuroendocrinol 30:548-557. CrossRef Medline

Higashida H, Yokoyama S, Huang JJ, Liu L, Ma WJ, Akther S, Higashida C,
Kikuchi M, Minabe Y, Munesue T (2012) Social memory, amnesia, and autism: brain oxytocin secretion is regulated by $\mathrm{NAD}(+)$ metabolites and single nucleotide polymorphisms of CD38. Neurochem Int. Advance online publication. Retrieved September 9, 2012. CrossRef Medline

Hollander E, Novotny S, Hanratty M, Yaffe R, DeCaria CM, Aronowitz BR, Mosovich S (2003) Oxytocin infusion reduces repetitive behaviors in adults with autistic and Asperger's disorders. Neuropsychopharmacology 28:193-198. CrossRef Medline

Hollander E, Bartz J, Chaplin W, Phillips A, Sumner J, Soorya L, Anagnostou E, Wasserman S (2007) Oxytocin increases retention of social cognition in autism. Biol Psychiatry 61:498-503. CrossRef Medline

Huber D, Veinante P, Stoop R (2005) Vasopressin and oxytocin excite distinct neuronal populations in the central amygdala. Science 308:245-248. CrossRef Medline

Hurlemann R, Patin A, Onur OA, Cohen MX, Baumgartner T, Metzler S, Dziobek I, Gallinat J, Wagner M, Maier W, Kendrick KM (2010) Oxytocin enhances amygdala-dependent, socially reinforced learning and emotional empathy in humans. J Neurosci 30:4999-5007. CrossRef Medline

Inoue H, Yamasue H, Tochigi M, Abe O, Liu X, Kawamura Y, Takei K, Suga M, Yamada H, Rogers MA, Aoki S, Sasaki T, Kasai K (2010) Association between the oxytocin receptor gene and amygdalar volume in healthy adults. Biol Psychiatry 68:1066-1072. CrossRef Medline

Inoue T, Kimura T, Azuma C, Inazawa J, Takemura M, Kikuchi T, Kubota Y, Ogita K, Saji F (1994) Structural organization of the human oxytocin receptor gene. J Biol Chem 269:32451-32456. Medline

Insel TR (1992) Oxytocin—a neuropeptide for affiliation: evidence from behavioral, receptor autoradiographic, and comparative studies. Psychoneuroendocrinology 17:3-35. CrossRef Medline

Insel TR (2010) The challenge of translation in social neuroscience: a review of oxytocin, vasopressin, and affiliative behavior. Neuron 65:768-779. CrossRef Medline

Insel TR, Young LJ (2001) The neurobiology of attachment. Nat Rev Neuroscience 2:129-136. CrossRef Medline

Israel S, Lerer E, Shalev I, Uzefovsky F, Riebold M, Laiba E, Bachner-Melman R, Maril A, Bornstein G, Knafo A, Ebstein RP (2009) The oxytocin receptor (OXTR) contributes to prosocial fund allocations in the dictator game and the social value orientations task. PLoS One 4:e5535. CrossRef Medline

Jacob S, Brune CW, Carter CS, Leventhal BL, Lord C, Cook EH Jr (2007) Association of the oxytocin receptor gene (OXTR) in Caucasian children and adolescents with autism. Neurosci Lett 417:6-9. CrossRef Medline

Jin D, Liu HX, Hirai H, Torashima T, Nagai T, Lopatina O, Shnayder NA, Yamada K, Noda M, Seike T, Fujita K, Takasawa S, Yokoyama S, Koizumi K, Shiraishi Y, Tanaka S, Hashii M, Yoshihara T, Higashida K, Islam MS, et al (2007) CD38 is critical for social behaviour by regulating oxytocin secretion. Nature 446:41-45. CrossRef Medline

Kemp AH, Guastella AJ (2011) The role of oxytocin in human affect: a novel hypothesis. Curr Dir Psychol Sci 20:222-231. CrossRef

Kendrick KM (2004) The neurobiology of social bonds. J Neuroendocrinol 16:1007-1008. CrossRef Medline

Kim HS, Sherman DK, Sasaki JY, Xu J, Chu TQ, Ryu C, Suh EM, Graham K, Taylor SE (2010) Culture, distress, and oxytocin receptor polymorphism (OXTR) interact to influence emotional support seeking. Proc Natl Acad Sci U S A 107:15717-15721. CrossRef Medline

Kim YS, Leventhal BL, Koh YJ, Fombonne E, Laska E, Lim EC, Cheon KA, Kim SJ, Kim YK, Lee H, Song DH, Grinker RR (2011) Prevalence of autism spectrum disorders in a total population sample. Am J Psychiatry 168:904-912. Medline

Kirsch P, Esslinger C, Chen Q, Mier D, Lis S, Siddhanti S, Gruppe H, Mattay VS, Gallhofer B, Meyer-Lindenberg A (2005) Oxytocin modulates neural circuitry for social cognition and fear in humans. J Neurosci 25:1148911493. CrossRef Medline

Knobloch HS, Charlet A, Hoffmann LC, Eliava M, Khrulev S, Cetin AH, Osten P, Schwarz MK, Seeburg PH, Stoop R, Grinevich V (2012) Evoked axonal oxytocin release in the central amygdala attenuates fear response. Neuron 73:553-566. CrossRef Medline

Kogan A, Saslow LR, Impett EA, Oveis C, Keltner D, Rodrigues Saturn S (2011) Thin-slicing study of the oxytocin receptor (OXTR) gene and the evaluation and expression of the prosocial disposition. Proc Natl Acad Sci U S A 108:19189-19192. CrossRef Medline

Kojima S, Alberts JR (2011) Oxytocin mediates the acquisition of filial, 
odor-guided huddling for maternally-associated odor in preweanling rats. Horm Behav 60:549-558. CrossRef Medline

Kosaka H, Munesue T, Ishitobi M, Asano M, Omori M, Sato M, Tomoda A, Wada Y (2012) Long-term oxytocin administration improves social behaviors in a girl with autistic disorder. BMC Psychiatry 12:110. CrossRef Medline

Kosfeld M, Heinrichs M, Zak PJ, Fischbacher U, Fehr E (2005) Oxytocin increases trust in humans. Nature 435:673-676. CrossRef Medline

Krueger F, Parasuraman R, Iyengar V, Thornburg M, Weel J, Lin M, Clarke E, McCabe K, Lipsky RH (2012) Oxytocin receptor genetic variation promotes human trust behavior. Front Hum Neurosci 6:4. CrossRef Medline

Kurth F, Narr KL, Woods RP, O’Neill J, Alger JR, Caplan R, McCracken JT, Toga AW, Levitt JG (2011) Diminished gray matter within the hypothalamus in autism disorder: a potential link to hormonal effects? Biol Psychiatry 70:278-282. CrossRef Medline

Labuschagne I, Phan KL, Wood A, Angstadt M, Chua P, Heinrichs M, Stout JC, Nathan PJ (2010) Oxytocin attenuates amygdala reactivity to fear in generalized social anxiety disorder. Neuropsychopharmacology 35: 2403-2413. CrossRef Medline

Labuschagne I, Phan KL, Wood A, Angstadt M, Chua P, Heinrichs M, Stout JC, Nathan PJ (2011) Medial frontal hyperactivity to sad faces in generalized social anxiety disorder and modulation by oxytocin. Int J Neuropsychopharmacol 15:883-896. CrossRef Medline

Lederbogen F, Kirsch P, Haddad L, Streit F, Tost H, Schuch P, Wüst S, Pruessner JC, Rietschel M, Deuschle M, Meyer-Lindenberg A (2011) City living and urban upbringing affect neural social stress processing in humans. Nature 474:498-501. CrossRef Medline

Leng G, Meddle SL, Douglas AJ (2008) Oxytocin and the maternal brain. Curr Opin Pharmacol 8:731-734. CrossRef Medline

Lerer E, Levi S, Salomon S, Darvasi A, Yirmiya N, Ebstein RP (2008) Association between the oxytocin receptor (OXTR) gene and autism: relationship to vineland adaptive behavior scales and cognition. Mol Psychiatry 13:980-988. CrossRef Medline

Lischke A, Gamer M, Berger C, Grossmann A, Hauenstein K, Heinrichs M, Herpertz SC, Domes G (2012) Oxytocin increases amygdala reactivity to threatening scenes in females. Psychoneuroendocrinology 37:1431-1438. CrossRef Medline

Liu X, Kawamura Y, Shimada T, Otowa T, Koishi S, Sugiyama T, Nishida H, Hashimoto O, Nakagami R, Tochigi M, Umekage T, Kano Y, Miyagawa T, Kato N, Tokunaga K, Sasaki T (2010) Association of the oxytocin receptor (OXTR) gene polymorphisms with autism spectrum disorder (ASD) in the Japanese population. J Hum Genet 55:137-141. CrossRef Medline

Lucht MJ, Barnow S, Sonnenfeld C, Rosenberger A, Grabe HJ, Schroeder W, Völzke H, Freyberger HJ, Herrmann FH, Kroemer H, Rosskopf D (2009) Associations between the oxytocin receptor gene (OXTR) and affect, loneliness and intelligence in normal subjects. Prog Neuropsychopharmacol Biol Psychiatry 33:860-866. CrossRef Medline

Luijk MP, Roisman GI, Haltigan JD, Tiemeier H, Booth-Laforce C, van Ijzendoorn MH, Belsky J, Uitterlinden AG, Jaddoe VW, Hofman A, Verhulst FC, Tharner A, Bakermans-Kranenburg MJ (2011) Dopaminergic, serotonergic, and oxytonergic candidate genes associated with infant attachment security and disorganization? In search of main and interaction effects. J Child Psychol Psychiatry 52:1295-1307. CrossRef Medline

Lukas M, Toth I, Reber SO, Slattery DA, Veenema AH, Neumann ID (2011) The neuropeptide oxytocin facilitates pro-social behavior and prevents social avoidance in rats and mice. Neuropsychopharmacology 36:21592168. CrossRef Medline

Malik AI, Zai CC, Abu Z, Nowrouzi B, Beitchman JH (2012) The role of oxytocin and oxytocin receptor gene variants in childhood-onset aggression. Genes Brain Behav 11:545-551. CrossRef Medline

Marsh AA, Yu HH, Pine DS, Gorodetsky EK, Goldman D, Blair RJR (2012) The influence of oxytocin administration on responses to infant faces and potential moderation by OXTR genotype. Psychopharmacology (Berl). Advance online publication. Retrieved September 9, 2012. CrossRef Medline

McCall C, Singer T (2012) The animal and human neuroendocrinology of social cognition, motivation and behavior. Nat Neurosci 15:681-688. CrossRef Medline

McCarthy MM, Altemus M (1997) Central nervous system actions of oxytocin and modulation of behavior in humans. Mol Med Today 3:269275. CrossRef Medline

Meyer-Lindenberg A, Weinberger DR (2006) Intermediate phenotypes and genetic mechanisms of psychiatric disorders. Nat Rev Neurosci 7:818827. CrossRef Medline

Meyer-Lindenberg A, Kolachana B, Gold B, Olsh A, Nicodemus KK, Mattay V, Dean M, Weinberger DR (2009) Genetic variants in AVPR1A linked to autism predict amygdala activation and personality traits in healthy humans. Mol Psychiatry 14:968-975. CrossRef Medline

Meyer-Lindenberg A, Domes G, Kirsch P, Heinrichs M (2011) Oxytocin and vasopressin in the human brain: social neuropeptides for translational medicine. Nat Rev Neurosci 12:524-538. CrossRef Medline

Modahl C, Green L, Fein D, Morris M, Waterhouse L, Feinstein C, Levin H (1998) Plasma oxytocin levels in autistic children. Biol Psychiatry 43: 270-277. CrossRef Medline

Modi ME, Young LJ (2012) The oxytocin system in drug discovery for autism: animal models and novel therapeutic strategies. Horm Behav 61: 340-350. CrossRef Medline

Montag C, Fiebach CJ, Kirsch P, Reuter M (2011) Interaction of 5-HTTLPR and a variation on the oxytocin receptor gene influences negative emotionality. Biol Psychiatry 69:601-603. CrossRef Medline

Montag C, Brockmann EM, Bayerl M, Rujescu D, Müller DJ, Gallinat J (2012) Oxytocin and oxytocin receptor gene polymorphisms and risk for schizophrenia: a case-control study. World J Biol Psychiatry. Advance online publication. Retrieved September 9, 2012. CrossRef Medline

Munesue T, Yokoyam S, Nakamura K, Anitha A, Yamada K, Hayashi K, Asaka T, Liu HX, Jin D, Koizumi K, Islam MS, Huang JJ, Ma WJ, Kim UH, Kim SJ, Park K, Kim D, Kikuchi M, Ono Y, Nakatani H, et al (2010) Two genetic variants of CD38 in subjects with autism spectrum disorder and controls. Neurosci Res 67:181-191. CrossRef Medline

Neumann ID (2002) Involvement of the brain oxytocin system in stress coping: interactions with the hypothalamo-pituitary-adrenal axis. Prog Brain Res 139:147-162. CrossRef Medline

Neumann ID (2009) The advantage of social living: brain neuropeptides mediate the benficial consequences of sex and motherhood. Front Neuroendocrinol 30:483-496. CrossRef Medline

Neumann ID, Torner L, Wigger A (2000a) Brain oxytocin: differential inhibition of neuroendocrine stress responses and anxiety-related behaviour in virgin, pregnant and lactating rats. Neuroscience 95:567-575. Medline

Neumann ID, Krömer SA, Toschi N, Ebner K (2000b) Brain oxytocin inhibits the (re)activity of the hypothalamo-pituitary-adrenal axis in male rats: involvement of hypothalamic and limbic brain regions. Regul Pept 96:31-38. CrossRef Medline

Norman GJ, Hawkley L, Luhmann M, Ball AB, Cole SW, Berntson GG, Cacioppo JT (2012) Variation in the oxytocin receptor gene influences neurocardiac reactivity to social stress and HPA function: a population based study. Horm Behav 61:134-139. CrossRef Medline

Nowak R, Keller M, Levy F (2011) Mother-young relationships in sheep: a model for a multidisciplinary approach of the study of attachment in mammals. J Neuroendocrinol 23:1042-1053. CrossRef Medline

O'Connell G, Whalley HC, Mukherjee P, Stanfield AC, Montag C, Hall J, Reuter M (2012) Association of genetic variation in the promoter region of OXTR with differences in social affective neural processing. J Behav Brain Sci 2:60-66. CrossRef

Pedersen CA, Gibson CM, Rau SW, Salimi K, Smedley KL, Casey RL, Leserman J, Jarskog LF, Penn DL (2011) Intranasal oxytocin reduces psychotic symptoms and improves Theory of Mind and social perception in schizophrenia. Schizophr Res 132:50-53. CrossRef Medline

Peper JS, Brouwer RM, Boomsma DI, Kahn RS, Hulshoff Pol HE (2007) Genetic influences on human brain structure: a review of brain imaging studies in twins. Hum Brain Mapp 28:464-473. CrossRef Medline

Petrovic P, Kalisch R, Singer T, Dolan RJ (2008) Oxytocin attenuates affective evaluations of conditioned faces and amygdala activity. J Neurosci 28:6607-6615. CrossRef Medline

Pezawas L, Meyer-Lindenberg A, Drabant EM, Verchinski BA, Munoz KE, Kolachana BS, Egan MF, Mattay VS, Hariri AR, Weinberger DR (2005) 5-HTTLPR polymorphism impacts human cingulate-amygdala interactions: a genetic susceptibility mechanism for depression. Nat Neurosci 8:828-834. CrossRef Medline

Pobbe RL, Pearson BL, Defensor EB, Bolivar VJ, Young WS 3rd, Lee HJ, Blanchard DC, Blanchard RJ (2012) Oxytocin receptor knockout mice display deficits in the expression of autism-related behaviors. Horm Behav 61:436-444. CrossRef Medline 
Porges SW (2003a) The Polyvagal Theory: phylogenetic contributions to social behavior. Physiol Behav 79:503-513. CrossRef Medline

Porges SW (2003b) Social engagement and attachment: a phylogenetic perspective. Ann N Y Acad Sci 1008:31-47. CrossRef Medline

Autism and Developmental Disabilities Monitoring Network Surveillance Year 2008 Principal Investigators, Centers for Disease Control and Prevention (2012) Prevalence of autism spectrum disorders-Autism and Developmental Disabilities Monitoring Network, 14 sites, United States, 2008. MMWR Surveill Summ 61:1-19. Medline

Riem MME, Bakermans-Kranenburg MJ, Pieper S, Tops M, Boksem MA, Vermeiren RR, van Ijzendoorn MH, Rombouts SA (2011) Oxytocin modulates amygdala, insula, and inferior frontal gyrus responses to infant crying: a randomized controlled trial. Biol Psychiatry 70:291-297. CrossRef Medline

Riem MM, van Ijzendoorn MH, Tops M, Boksem MA, Rombouts SA, Bakermans-Kranenburg MJ (2012) No laughing matter: intranasal oxytocin administration changes functional brain connectivity during exposure to infant laughter. Neuropsychopharmacology 37:1257-1266. CrossRef Medline

Rilling JK, DeMarco AC, Hackett PD, Thompson R, Ditzen B, Patel R, Pagnoni G (2012) Effects of intranasal oxytocin and vasopressin on cooperative behavior and associated brain activity in men. Psychoneuroendocrinology 37:447-461. CrossRef Medline

Rimmele U, Hediger K, Heinrichs M, Klaver P (2009) Oxytocin makes a face in memory familiar. J Neurosci 29:38-42. CrossRef Medline

Rodrigues SM, Saslow LR, Garcia N, John OP, Keltner D (2009) Oxytocin receptor genetic variation relates to empathy and stress reactivity in humans. Proc Natl Acad Sci U S A 106:21437-21441. CrossRef Medline

Rubin LH, Carter CS, Drogos L, Jamadar R, Pournajafi-Nazarloo H, Sweeney JA, Maki PM (2011) Sex-specific associations between peripheral oxytocin and emotion perception in schizophrenia. Schizophr Res 130:266270. CrossRef Medline

Russell JA, Leng G, Douglas AJ (2003) The magnocellular oxytocin system, the fount of maternity: adaptations in pregnancy. Front Neuroendocrinol 24:27-61. CrossRef Medline

Saphire-Bernstein S, Way BM, Kim HS, Sherman DK, Taylor SE (2011) Oxytocin receptor gene (OXTR) is related to psychological resources. Proc Natl Acad Sci U S A 108:15118-15122. CrossRef Medline

Sauer C, Montag C, Wörner C, Kirsch P, Reuter M (2012) Effects of a common variant in the CD38 gene on social processing in an oxytocin challenge study: possible links to autism. Neuropsychopharmacology 37: 1474-1482. CrossRef Medline

Savaskan E, Ehrhardt R, Schulz A, Walter M, Schächinger H (2008) Postlearning intranasal oxytocin modulates human memory for facial identity. Psychoneuroendocrinology 33:368-374. CrossRef Medline

Seyfarth RM, Cheney DL (2012) The evolutionary origins of friendship. Annu Rev Psychol 63:153-177. CrossRef Medline

Shamay-Tsoory SG, Fischer M, Dvash J, Harari H, Perach-Bloom N, Levkovitz Y (2009) Intranasal administration of oxytocin increases envy and schadenfreude (gloating). Biol Psychiatry 66:864-870. CrossRef Medline

Silk JB, House BR (2011) Evolutionary foundations of human prosocial sentiments. Proc Natl Acad Sci U S A 108 [Suppl 2]:10910-10917. CrossRef

Silk JB, Alberts SC, Altmann J (2003) Social bonds of female baboons enhance infant survival. Science 302:1231-1234. CrossRef Medline

Simeon D, Bartz J, Hamilton H, Crystal S, Braun A, Ketay S, Hollander E (2011) Oxytocin administration attenuates stress reactivity in borderline personality disorder: a pilot study. Psychoneuroendocrinology 36:1418-1421. CrossRef Medline

Skuse DH, Gallagher L (2009) Dopaminergic-neuropeptide interactions in the social brain. Trends Cogn Sci 13:27-35. CrossRef Medline

Smith AS, Agmo A, Birnie AK, French JA (2010) Manipulation of the oxytocin system alters social behavior and attraction in pair-bonding primates, Callithrix penicillata. Horm Behav 57:255-262. CrossRef Medline

Sripada CS, Phan KL, Labuschagne I, Welsh R, Nathan PJ, Wood AG (2012) Oxytocin enhances resting-state connectivity between amygdala and medial frontal cortex. Int J Neuropsychopharmacol May 30:1-6. CrossRef Medline

Strathearn L, Fonagy P, Amico J, Montague PR (2009) Adult attachment predicts maternal brain and oxytocin response to infant cues. Neuropsychopharmacology 34:2655-2666. CrossRef Medline

Striepens N, Kendrick KM, Maier W, Hurlemann R (2011) Prosocial effects of oxytocin and clinical evidence for its therapeutic potential. Front Neuroendocrinol 32:426-450. CrossRef Medline

Takayanagi Y, Yoshida M, Bielsky IF, Ross HE, Kawamata M, Onaka T, Yanagisawa T, Kimura T, Matzuk MM, Young LJ, Nishimori K (2005) Pervasive social deficits, but normal parturition, in oxytocin receptordeficient mice. Proc Natl Acad Sci U S A 102:16096-16101. CrossRef Medline

Tansey KE, Brookes KJ, Hill MJ, Cochrane LE, Gill M, Skuse D, Correia C, Vicente A, Kent L, Gallagher L, Anney RJ (2010) Oxytocin receptor (OXTR) does not play a major role in the aetiology of autism: genetic and molecular studies. Neurosci Lett 474:163-167. CrossRef Medline

Theodoridou A, Rowe AC, Penton-Voak IS, Rogers PJ (2009) Oxytocin and social perception: oxytocin increases perceived facial trustworthiness and attractiveness. Horm Behav 56:128-132. CrossRef Medline

Tost H, Kolachana B, Hakimi S, Lemaitre H, Verchinski BA, Mattay VS, Weinberger DR, Meyer-Lindenberg A (2010) A common allele in the oxytocin receptor gene (OXTR) impacts prosocial temperament and human hypothalamic-limbic structure and function. Proc Natl Acad Sci U S A 107:13936-13941. CrossRef Medline

Tost H, Kolachana B, Verchinski BA, Bilek E, Goldman AL, Mattay VS, Weinberger DR, Meyer-Lindenberg A (2011) Neurogenetic effects of OXTR rs 2254298 in the extended limbic system of healthy caucasian adults. Biol Psychiatry 70:E37-E39. CrossRef Medline

Van Ijzendoorn MH, Bakermans-Kranenburg MJ (2012) A sniff of trust: meta-analysis of the effects of intranasal oxytocin administration on face recognition, trust to in-group, and trust to out-group. Psychoneuroendocrinology 37:438-443. Medline

van Leengoed E, Kerker E, Swanson HH (1987) Inhibition of post-partum maternal behaviour in the rat by injecting an oxytocin antagonist into the cerebral ventricles. J Endocrinol 112:275-282. CrossRef Medline

Viviani D, Charlet A, van den Burg E, Robinet C, Hurni N, Abatis M, Magara F, Stoop R (2011) Oxytocin selectively gates fear responses though distinct outputs from the central amygdala. Science 333:104-107. CrossRef Medline

Walter NT, Montag C, Markett S, Felten A, Voigt G, Reuter M (2012) Ignorance is no excuse: moral judgments are influenced by a genetic variation on the oxytocin receptor gene. Brain Cogn 78:268-273. CrossRef Medline

Walum H, Lichtenstein P, Neiderhiser JM, Reiss D, Ganiban JM, Spotts EL, Pedersen NL, Anckarsäter H, Larsson H, Westberg L (2012) Variation in the oxytocin receptor gene is associated with pair-bonding and social behavior. Biol Psychiatry 71:419-426. CrossRef Medline

Wermter AK, Kamp-Becker I, Hesse P, Schulte-Körne G, Strauch K, Remschmidt H (2010) Evidence for the involvement of genetic variation in the oxytocin receptor gene (OXTR) in the etiology of autistic disorders on high-functioning level. Am J Med Genet B Neuropsychiatr Genet 153B: 629-639. CrossRef Medline

Williams JR, Carter CS, Insel T (1992) Partner preference development in female prairie voles is facilitated by mating or the central infusion of oxytocin. Ann N Y Acad Sci 652:487-489. CrossRef Medline

Winslow JT, Hearn EF, Ferguson J, Young LJ, Matzuk MM, Insel TR (2000) Infant vocalization, adult aggression, and fear behavior of an oxytocin null mutant mouse. Horm Behav 37:145-155. CrossRef Medline

Wu N, Li Z, Su Y (2012) The association between oxytocin receptor gene polymorphism (OXTR) and trait empathy. J Affect Disord 138:468-472. CrossRef Medline

Wu S, Jia M, Ruan Y, Liu J, Guo Y, Shuang M, Gong X, Zhang Y, Yang X, Zhang D (2005) Positive association of the oxytocin receptor gene (OXTR) with autism in the Chinese Han population. Biol Psychiatry 58:74-77. CrossRef Medline

Yamasue H, Kuwabara H, Kawakubo Y, Kasai K (2009) Oxytocin, sexually dimorphic features of the social brain, and autism. Psychiatry Clin Neurosci 63:129-140. CrossRef Medline

Yamasue H, Suga M, Yahata N, Inoue H, Tochigi M, Abe O, Liu X, Kawamura Y, Rogers MA, Takei K, Yamada H, Aoki S, Sasaki T, Kasai K (2011) Reply to: neurogenetic effects of OXTR rs2254298 in the extended limbic system of healthy caucasian adults. Biol Psychiatry 70:E41-E42. CrossRef

Young LJ (2002) The neurobiology of social recognition, approach, and avoidance. Biol Psychiatry 51:18-26. CrossRef Medline

Young LJ, Wang Z, Insel TR (1998) Neuroendocrine bases of monogamy. Trends Neurosci 21:71-75. CrossRef Medline

Young LJ, Lim MM, Gingrich B, Insel TR (2001) Cellular mechanisms of social attachment. Horm Behav 40:133-138. CrossRef Medline 
Young LJ, Murphy Young AZ, Hammock EA (2005) Anatomy and neurochemistry of the pair bond. J Comp Neurol 493:51-57. CrossRef Medline

Yrigollen CM, Han SS, Kochetkova A, Babitz T, Chang JT, Volkmar FR, Leckman JF, Grigorenko EL (2008) Genes controlling affiliative behav- ior as candidate genes for autism. Biol Psychiatry 63:911-916. CrossRef Medline

Zak PJ, Stanton AA, Ahmadi S (2007) Oxytocin increases generosity in humans. PLoS One 2:e1128. CrossRef Medline 